\title{
INCOME TAX DEDUCTIBILITY OF ATTORNEYS' FEES INCURRED IN UNSUCCESSFUL CRIMINAL DEFENSE
}

In the recent case of Tellier v. Commissioner ${ }^{1}$ the Court of Appeals for the Second Circuit overruled a long standing precedent by declaring deductible litigation expenses arising out of the conduct of a business regardless of the type or the outcome of the litigation. The taxpayerpetitioner, a dealer in securities, had been tried and convicted of violations of federal securities and mail fraud statutes growing out of his business activities. He claimed an income tax deduction for expenditures incurred in his unsuccessful defense of the criminal proceeding. The Commissioner's disallowance of the deduction was sustained by the Tax Court. ${ }^{2}$ Sitting en banc, the court of appeals reversed unanimously, holding that such expenses are "ordinary and necessary" within the meaning of section 162(a) of the Internal Revenue Code of 1954, and that no sharply defined public policy is frustrated by allowing the deduction.

The 1954 Code allows a deduction for "all the ordinary and necessary expenses" incurred in carrying on a business or trade, ${ }^{3}$ in producing or collecting income, ${ }^{4}$ or in managing and maintaining income producing property. ${ }^{5}$ The statutory language has been construed to require only (1) that the expenditure be directly connected with or proximately result from the taxpayer's business or income producing activity; ${ }^{6}(2)$ that the

1342 F.2d 690 (2d Cir. 1965), cert. granted, 34 U.S.L. WeEK 3118 (U.S. Oct. $12,1965)$.

2 Walter F. Tellier, 22 CCH Tax Ct. Mem. 1062 (1963).

3 INT. REv. CoDE of 1954, \$162(a).

4 INT. Rev. CODE of 1954, §212(1).

5 INT. REv. Code of 1954, \$212(2). The standards for "ordinary and necessary" are the same with respect to both $\$ 162$ and $\$ 212$. See, e.g., United States v. Gilmore, 372 U.S. 39, 45 (1963) ; Trust of Bingham v. Commissioner, 325 U.S. 365, 373-74 (1945). However, $\$ 212$ was new in 1942, 56 Stat. 819, whereas the provisions of $\S 162$ date back to the 1919 Code, 40 Stat. 1066, 1077. Since most of the cases relevant to this Comment deal with business expenses, only deductions claimed under $\$ 162$ will be discussed explicitly. It should be understood that the same considerations are applicable to expenses incurred in income producing activities outside the context of a trade or business.

6 E.g., Kornhauser v. United States, 276 U.S. 145, 153 (1928). There is a general prohibition of deductions for personal expenses, INT. REv. CODE of 1954, $\$ 262$, which may become relevant in cases involving the deduction of legal fees. Thus, although a suit threatens to injure the taxpayer in his business or income producing capacity, his litigation expenses will be nondeductible if the origin and nature of the suit are personal. See, e.g., United States v. Gilmore, 372 U.S. 39 (1963) (wife's claims against taxpayer's business assets successfully resisted in divorce action); Lloyd v. Commissioner, 55 F.2d 842 (7th Cir. 1932) (action for slander brought and won by taxpayer). However, some courts have held expenses incurred in an unsuccessful defense to be personal when they would have been allowed under $\$ 162$ if the taxpayer had won, indicating that the actual ground of disallowance was public policy. Compare Tinkoff v. Commissioner, $120 \mathrm{~F} .2 \mathrm{~d} 564$ (7th Cir.), cert. denied, 314 U.S. 581 (1941) (unstuccessful attempt to expunge order of suspension of attorney taxpayer from practice before Treasury Department); Tracy v. United States, 151 
expenditure be common and accepted in that type of business or activity ; 7 and (3) that the expenditure be appropriate at the time or helpful to the taxpayer. ${ }^{8}$ Just as the Code includes income derived from illegal activities within gross income, ${ }^{9}$ so it imposes no requirement for deductions that expenses be lawful or arise out of lawful activities. ${ }^{10}$ Nevertheless, the courts have created a "public policy" exception to the statutory language which forbids the deduction of certain expenses, otherwise "ordinary and necessary," 11 involving or related to unlawful activities.

As articulated by the Supreme Court, the rule is that "a finding of 'necessity' cannot be made . . . if allowance of the deduction would frustrate sharply defined national or state policies ${ }^{12}$ proscribing particular

Ct. Cl. 618, 284 F.2d 379 (1960) (unsuccessful attempt to forestall tax evasion prosecution), and Henry L. Peckham, 40 T.C. 315 (1963), aff'd, 327 F.2d 855 (4th Cir. 1964) (doctor taxpayer convicted of performing criminal abortion), with Commissioner v. People's-Pittsburgh Trust Co., 60 F.2d 187 (3d Cir. 1932) (taxpayer, director of company, acquitted of income tax evasion), and John W. Clark, 30 T.C. 1330 (1958) (charges of criminal assault while on job dismissed). Hereafter it will be assumed that the expenditures in question are business expenses according to the. Supreme Court's construction requiring only direct connection with or proximate result from the taxpayer's business.

7 E.g., Lilly v. Commissioner, 343 U.S. 90, 93 (1952) ; Commissioner v. Heininger, 320 U.S. 467, 471 (1943); Deputy v. du Pont, 308 U.S. 488, 495 (1940); Welsh v. Helvering, 290 U.S. 111, 114 (1933).

8 E.g., Lilly v. Commissioner, supra note 7, at 93-94; Commissioner v. Heininger, supra note 7 , at 471 . These cases make it clear that the expenditure need not in fact aid the business or result in the production of income. See Trust of Bingham v. Commissioner, 325 U.S. 365 (1945). Nevertheless, one ground relied on by the Tax Court in disallowing legal expenses incurred in an unsuccessful criminal defense has been that "the fees were not incurred in the actual production of the income of the ... business and did not enable ${ }^{-}$[the taxpayer] to continue his . . . business.; C. W. Thomas, 16 T.C. 1417,1418 (1951). Here, as in some cases labeling such expenses "pérsonal," see note 6 supra, the court indulged in an improper interpretation of the Code to buttress its actual reliance upon a public policy outside the statute. Compare note 11 infra.

O United States v. Sullivan, 274 U.S. 259, 263 (1927).

10 See, e.g., Commissioner v. Heininger, 320 U.S. 467, 474 (1943); Tellier v. Commissioner, 342 F.2d 690, 692-93 (2d Cir. 1965), cert. granted, 34 U.S.L. WeEK 3118 (U.S. Oct. 12, 1965) ; 50 CoNG. Rec. 3849 (1913) (remarks of Senator Williams).

11 Some courts have accepted the argument that any illegal activity is extraordinary and unnecessary, and thus that no expenditure occasioned by the activity can be deemed ordinary and necessary. See, e.g., National Outdoor Advertising Bureau, Inc. v. Helvering, 89 F.2d 878, 881 (2d Cir. 1937); David R. Faulk, 26 T.C. 948, 951 (1956); Sarah Backer, 1 B.T.A. 214, 217 (1924). 'However, as the Second Circuit has now recognized,

To the extent that the equation of illegality with extraordinary and unnecessary is not question begging, it is applying special meanings to "ordinary and necessary" which are not applied in other connections. So long as the expense arises out of the conduct of the business and is a required outlay it ought to be considered ordinary and necessary.

Tellier v. Commissioner, supra note 10 , at 694 ; see Note, 54 HARv. I. REv. 852, 856-57 (1941); Note, 13 StaN. L. Rev. 92, 98-99 (1960); Comment, 72 Yale L.J. 108, 113 n.20 (1962). Of course, some expenditures, particularly those illegal or unethical in themselves, may validly be disallowed as extraordinary if they are uncommon or unaccepted ways of doing business. See, e.g., United Draperies, Inc. v. Commissioner, 340 F.2d 936 (7th Cir. 1964), cert. denied, 86 Sup. Ct. 30 (1965); Reid, Disallowance of Tax Deductions on Grounds of Public Policy-A Critique, 17 FED. B.J. 575, 582-83 (1957) ; cf. Commissioner v. Doyle, 231 F.2d 635, 637 (7th Cir. 1956) (dictum).

12 It is interesting that the Court and most commentators draw no distinction between national and state policies, even though it might appear that the federal 
types of conduct, evidenced by some governmental declaration thereof." 13 The Court has found such frustration in only two types of cases: It has upheld Treasury Regulations denying deductions for certain types of lobbying expenses, ${ }^{14}$ and it has held that criminal fines may be disallowed. ${ }^{15}$

On the other hand, the Supreme Court has emphasized the intent of the Code to tax net income regardless of its source. ${ }^{16}$ Thus it has held

government would have a more valid interest in deviating from the neutrality of the Code to avoid the frustration of federal law than that of state law. One commentator has suggested such a distinction with respect to the deductibility of expenditures which are illegal per se. Lurie, Deductibility of "Illegal" Expenses, 11 N.Y.U. INST. on FED. TAX 1189, 1191 (1953).

13 Tank Truck Rentals, Inc. v. Commissioner, 356 U.S. 30, 33-34 (1958). (Footnote added.) Thus the Court would find the expense "unnecessary" as a matter of law on public policy grounds, even though it might in fact be "necessary" as that word is used in the Code. See note 11 supra. It appears that the "governmental declaration" must be through legislation or in certain cases, see note 14 infra, through administrative regulations with apparent congressional acquiescence. See Lilly v. Commissioner, 343 U.S. 90, 94-97 (1952); McDonald, Deduction of Attorneys' Fees for Federal Income Tax Purposes, 103 U. PA. L. REv. 168, 179 (1954); cf. Schwartz, Business Expenses Contrary to Public Policy: An Evaluation of the Lilly Case, 8 Tax L. Rev. 241, 248 (1953); Note, 51 Colum. L. Rev. 752 (1951).

14 Cammarano v. United States, 358 U.S. 498 (1959); Textile Mills Sec. Corp. v. Commissioner, 314 U.S. 326 (1941). In these cases the Regulations had been in force for many years, and Congress was assumed to have acquiesced in them through subsequent reenactments of the relevant code provisions. See Lilly v. Commissioner, 343 U.S. 90,95 (1952). In addition, the lobbying cases uniquely involve the doctrine that business men should not be allowed deductions unavailable to other taxpayers undertaking similar activities. See generally Comment, 69 YALE L.J. 1017 (1960).

15 Tank Truck Rentals, Inc. v. Commissioner, 366 U.S. 30 (1958); Hoover Motor Express Co. v. United States, 356 U.S. 38 (1958) (alternative holding). The Court has also indicated that expenditures which are in themselves illegal and which would be so even if the taxpayer's business were lawful, compare text accompanying note 18 infra, should be disallowed because a direct frustration of the prohibiting statute would result from their allowance. See Tank Truck Rentals, Inc. v. Commissioner, supra at 35 (dictum); cf. Lilly v. Commissioner, 343 U.S. 90, 94-95 (1952) (dictum); United States v. Sullivan, 274 U.S. 259,264 (1927) (dictum). The lower courts have so held without exception, including within the same rubric payments made unethically to influence government officials. See, e.g., Dixie Mach. Welding \& Metal Works, Inc. v. United States, 315 F.2d 439 (5th Cir.), cert. denied, 373 U.S. 950 (1963) (payments in violation of state bribery law); Rugel v. Commissioner, 127 F.2d 393 (8th Cir. 1942) (payments for political influence to obtain public contracts); Boyle, Flagg \& Seaman, Inc., 25 T.C. 43 (1955) (payments in violation of state insurance law); Ralph Leonard Polk, 7 CCH Tax Ct. Mem. 51 (1948), aff'd sub nom. Cohen v. Commissioner, 176 F.2d 394 (10th Cir. 1949) ("protection" payments to state and county officials by operators of gambling house). Compare note 17 infra and accompanying text.

16 See, e.g., Commissioner v. Sullivan, 356 U.S. 27, 29 (1958) ; Commissioner v. Heininger, 320 U.S. 467, 474 (1943); McDonald v. Commissioner, 323 U.S. 57, 66-67 (1944) (Black, J., dissenting). Although taxable income for Code purposes is technically defined as gross income less allowable deductions, there was clearly a notion of commercial net income in the minds of the framers of the income tax sections, who intended, in crude terms, to tax "what . . . [an individual] has at the end of the year after deducting from his receipts his expenditures or losses." 50 CoNG. REC. 3849 (1913) (remarks of Senator Williams). See generally Keesling, Illegal Transactions and the Income Tax, 5 U.C.L.A.L. REv. 26 (1958); Paul, The Use of Public Policy by the Commissioner in Disallowing Deductions, U. So. CAL. 1954 TAX INST. 715 ; Reid, supra note 11.

Thus the common assertion that deductions are a matter of legislative grace, see, e.g., Deputy v. du Pont, 308 U.S. 488, 493 (1940) ; New Colonial Ice Co. v. Helvering, 292 U.S. 435,440 (1934), adds no force to the argument for deductibility on public policy grounds. Congress did provide for the deduction of ordinary and necessary business expenses and, as one commentator has said, deductions once allowed through the "grace" of Congress are not a matter of judicial grace. Reid, supra note 11, at 581. 
that expenditures thought to be "immoral," but which do not violate the criminal law, may be deducted if they are ordinary and necessary. ${ }^{17}$ The Court has also held deductible amounts spent for rent and employees' salaries in the conduct of an illegal gambling enterprise, even though the payments themselves violated the state penal statute. ${ }^{18}$ And, in Commission v. Heininger, ${ }^{19}$ the Court held deductible legal fees incurred during hearings before the Postmaster General which resulted during a fraud order that threatened to destroy the taxpayer's business and in an unsuccessful effort to obtain an injunction against the fraud order.

There had never been any doubt that a taxpayer might deduct legal expenses arising from the unsuccessful defense of a civil action brought by a private party, so long as it related to his business activities. ${ }^{20}$ The Commissioner and, until the Tellier case, the courts have viewed Heininger as extending deductibility only to situations involving administrative findings of "guilt" or other government instituted civil proceedings which are themselves inconclusive as to the guilt of the taxpayer. ${ }^{21}$ Thus they have

17 Lilly v. Commissioner, 343 U.S. 90 (1952). Lilly involved "kickbacks" to eye doctors made by the optician taxpayers in conformance with widespread practice, but in violation of professional standards of ethics. Such "immoral" expenditures had previously been disallowed along with those made illegal through legisiation. See also note 15 sipra.

18 Commissioner v. Sullivan, 356 U.S. 27 (1958).

19320 U.S. 467 (1943).

20 See, e.g., Foss v. Commissioner, 75 F.2d 326 (1st Cir. 1935); John W. Clark, 30 T.C. 1330 (1958). This allowance corresponded in general to the allowance of amounts paid for primarily compensatory damages or settlements in private civil suits. See, e.g., Anderson v. Commissioner, 81 F.2d 457 (10th Cir. 1936); Helvering v. Hampton, 79 F.2d 358 (9th Cir. 1935). It now appears that the Commissioner will allow all civil damages paid to private parties, including treble damages in antitrust suits, without regard to their compensatory or punitive nature. See Rev. Rul. 64-224, 1964-2 CUM. BuLx. 52, 113 U. PA. L. REv. 954 (1965). A fortiori legal expenses will be allowed in such cases.

21 See Rev. Rul. 62-175, 1962-2 CuM. BulL. 50; Commissioner v. Shapiro, 278 F.2d 556 (7th Cir. 1960); Hopkins v. Commissioner, 271 F.2d 166 (6th Cir. 1959); Commissioner v. Schwartz, 232 F.2d 94 (5th Cir. 1956); Greene Motor Co., 5 T.C. 314 (1945), acq., 1945 CuM. Burx. 3; Longhorn Portiand Cement Co., 3 T.C. 310 (1944), acq. in part, 1944 Cum. BuLc. 18 (as to allowance of attorneys' fees in civil antitrust action brought by state government), rev'd in part, $148 \mathrm{~F} .2 \mathrm{~d} 276$ (5th Cir.), cert. denied, 326 U.S. 728 (1945) (as to allowance of settlement payment to the state). But see David R. Faulk, 26 T.C. 948 (1956) (disallowing both attorneys' fees and double damages in civil suit brought by federal government); $c f$. Bell v. Commissioner, 320 F.2d 953 (8th Cir. 1963) (disallowance of attorneys' fees involved in appearances before C.P.A. disciplinary boards after taxpayer's conviction of crime); Estate of Buder, 22 CCH Tax Ct. Mem. 300 (1963), aff'd on other issues, 330 F.2d 441 (8th Cir. 1964) (disallowance of fees spent in unsuccessfully resisting disbarment proceedings); Thomas A. Joseph, 26 T.C. 562 (1956) (the same).

The Longhorn case, supra, exemplifies the rare situation in which essentially "penal" payments to the government have been held nondeductible when legal expenses were allowed. See note 28 infra and accompanying text. Before Heininger, both amounts paid as civil damages to the government and legal fees incurred in unsuccessful civil suits or administrative hearings against the government were nonductible. See, e.g., Tinkoff v. Commissioner, 120 F.2d 564 (7th Cir. 1941); National Outdoor Advertising Bureau, Inc. v. Helvering, 89 F.2d 878 (2d Cir. 1937). Since Heininger, "compensatory" payments to the government, and consequently legal fees, have been allowed where the taxpayer's violation was unintentional and the statute was so administered as to impose punitive damages on willful violators only. See, e.g., United States v. Star-Kist Foods, Inc., 240 F.2d 759 (9th Cir. 1956); Jerry Rossman 
continued to apply the rule established by the Second Circuit in Burroughs Bldg. Material Co. v. Commissioner, ${ }^{22}$ a pre-Heininger case overruled by the Tellier decision, that legal expenses incurred in criminal proceedings resulting in the taxpayer's conviction may not be deducted as ordinary and necessary business expenses. ${ }^{23}$

In Burroughs the taxpayer had claimed deductions for the fine imposed by the state trial court in a criminal prosecution for antitrust violations, as well as for the legal fees expended on the unsuccessful defense. Refusing to distinguish between these two types of expenses, ${ }^{24}$ the Second Circuit disallowed both on the basis of a general public policy against sanctioning expenditures occasioned by illegal activities.25 The Supreme Court's later agreement with the Second Circuit as to the nondeductibility of fines was based on its more limited "frustration" doctrine. 26 The Court repudiated the broad rationale of Burroughs, declaring that "the mere fact that an expenditure bears a remote relation to an illegal act" does not make it nondeductible. ${ }^{27}$ Nevertheless, the courts have continued to link attorneys' fees with fines without examining whether the allowance of fees would have the same "frustration" effect on governmentally declared policies as that attributed to fines by the Supreme Court, and have generally disallowed the fees whenever the payment of the penalty itself would have been disallowed. ${ }^{28}$

Corp. v. Commissioner, 175 F.2d 711 (2d Cir. 1949) ; Milton S. Kronheim \& Co. v. United States, $143 \mathrm{Ct}$. Cl. 390, 163 F. Supp. 620 (1958) ; cf. Tank Truck Rentals, Inc. v. Commissioner, 356 U.S. 30, 36-37 (1958) (dictum). But see McGraw-Edison Co. v. United States, 156 Ct. Cl. 590, 300 F.2d 453 (1962).

2247 F.2d 178 (2d Cir. 1931).

23 See, e.g., Bell v. Commissioner, 320 F.2d 953 (8th Cir. 1963) ; Acker v. Commissioner, $258 \mathrm{~F} .2 \mathrm{~d} 568$ (6th Cir. 1958), taxpayer's petition for cert. denied, 358 U.S. 940 (1959) ; Standard Coat, Apron \& Linen Serv., Inc., 40 T.C. 858 (1963) ; Henry L. Peckham, 40 T.C. 315 (1963), aff'd on alternative grounds, 327 F.2d 855 (4th Cir. 1964) ; Thomas A. Joseph, 26 T.C. 562 (1956); C. W. Thomas, 16 T.C. 1417 (1951); Simon Bloom, 7 CCH Tax Ct. Mem. 517 (1948); Anthony Cornero Stralla, 9 T.C. 801 (1947); Commissioner v. Shapiro, 278 F.2d 556, 560 (7th Cir. 1960) (dictum); Hopkins v. Commissioner, 271 F.2d 166, 167-68 (6th Cir. 1959) (dictum).

24 "If the fines and costs cannot be deducted, the legal expenses incurred in litigating the question whether the taxpayer violated the law and whether fines should be imposed should naturally fall with the fines themselves." Burroughs Bldg. Material Co. v. Commissioner, 47 F.2d 178, 180 (2d Cir. 1931). In most cases, as in Tellier, the courts were referring primarily to attorneys' fees when they spoke of "legal expenses." However, it would seem that expenditures for such items as transcripts and the taking of depositions should be grouped with attorneys' fees, and thus that they are included in the holding of the Tellier case. On the other hand, the Burroughs court may have been justified in its classification of court costs with fines, indicated in the above quotation. See Brookes, Litigation Expenses and the Income Tax, 12 TAX L. REv. 241, 273 (1957). The various considerations which would apply in determining the deductibility of different types of litigation expenses will not be considered here; "legal expenses" will hereafter refer only to attorneys' fees, which indeed constitute the most significant expenditure incurred in litigation.

25 Burroughs Bldg. Material Co. v. Commissioner, supra note 24, at 180.

26 Hoover Motor Express Co. v. United States, 356 U.S. 38 (1958) ; Tank Truck Rentals, Inc. v. Commissioner, 356 U.S. 30 (1958); see note 13 supra and accompanying text.

27 Commissioner v. Heininger, 320 U.S. 467, 474 (1943).

28 See Note, 13 Stan. L. Rev. 92, 102 (1960). The only exception has been where the state or national government has recovered a civil settlement payment from 
It is against this association of legal fees with penalties that the majority of commentators have argued. ${ }^{29}$ They claim that expenses incurred in an unsuccessful criminal defense are more closely allied with expenses which are held deductible even though incurred in the conduct of illegal business activities. If the gambling establishment is entitled to deduct its rent payments, it is argued, the proprietor of a lawful business should be able to deduct the expense of defending against criminal charges which threaten his business. ${ }^{30}$ Not only are attorneys' fees so expended lawful, but the sixth amendment makes their expenditure a right the deterrence of which could never be a valid public policy. ${ }^{31}$

This line of argument appears to contain several fallacies. It is of course true that conducting a lawful defense cannot be deemed an activity frustrating public policy, but neither can the payment of a fine by a convicted defendant. In the case of fines, frustration of public policy would occur if taxpayers were encouraged by deductibility to commit illegal acts.32 Similarly, allowing a deduction for the cost of defending a prosecution-and perhaps rendering that cost negligible in the case of the high income defendant-might encourage taxpayers to take the risk of being caught in illegal activities ${ }^{33}$ or encourage bad faith

the taxpayer which has been considered "penal" and thus nondeductible. See Commissioner v. Longhorn Portland Cement Co., 148 F.2d 276 ( 5 th Cir.), cert. denied, 326 U.S. 728 (1945); cf. Greene Motor Co., 5 T.C. 314 (1945), acq., 1945 CuM. BuLL. 3 . The attorneys' fees in such a case are deductible because directly covered by the holding of Heinimger. See note 21 supra and accompanying text.

29 E.g., Arent, Deductibility of Penalties and Related Expenses, 2 Anr. U. TAX Inst. 373, 381 (1949) ; Brookes, supra note 24, at 268; Krassner, Can a Deduction for Legal Fees Be Against Public Policy?, 26 TAxes 447, 448 (1948); Lamont, Controversial Aspects of Ordinary and Necessary Business Expenses, 42 TAXEs 808, 823-24 (1964) ; McDonald, supra note 13, at 180; Note, 54 HARv. L. Rev. 852, 856 (1941); Note, 13 Stan. L. REV. 92, 102 (1960). It should be noted that all of these writers would disallow the deduction of criminal penalties. On the other hand, there are those who would abolish any public policy exception to the language of the Code and allow deduction even of fines, contrary to the holdings of the Supreme Court, Tank Truck Rentals, Inc. v. Commissioner, 356 U.S. 30 (1958) ; Hoover Motor Express Co. v. United States, 356 U.S. 38 (1958) (alternative holding), and who thus find it unnecessary to make such a distinction. E.g., Paul, supra note 16, at 736-37; cf. Keesling, supra note 16, at 35-37; Reid, supra note 11, at 578, 581. An evaluation of the existing rule denying the deduction of fines and penalties is beyond the scope of this Comment.

30 E.g., Brookes, supra note 24, at 269; Sultan, Incone Tax Deductibility of Expenses Relating to Illegal Activity, 19 TAx L. Rev. 109, 116 (1963) ; Note, 13 Stan. L. REV. 92, 99 (1960).

31 See, e.g., Winokur, Deductibility of Legal and Other Professional Fees, U. So. Cal. 1963 Tax Inst. 457, 504; Note, 13 Stan. L. Rev. 92, 101 (1960). See also notes 49-55 infra and accompanying text.

32 Or, perhaps more significantly, statutory policy would be frustrated if deductibility allowed them to avoid part or all of the penal sanction. See notes $43-46$ infra and accompanying text. That taxpayers are encouraged by deductibility to commit illegal acts is a debatable premise and one hardly capable of testing; however, deductibility would seem no less likely to encourage violations in some cases than would a lessening of the penalty itself.

33 Although this would generally result only if the criminal law provided insuffcient penalties or inadequate enforcement, such reasoning is no less valid than the usual rationalization for the disallowance of illegal expenses, see note 15 supra, that allowance would encourage and render more profitable such expenditures, see, e.g., 
defenses. $^{34}$ Thus, if the allowance of fines is assumed to frustrate the deterrent function of a penal statute, so might the allowance of litigation fees, which allowance might be deemed to frustrate an additional policy against unconscionable defenses.

The commentators further argue that the Commissioner's and courts' conclusion that Heininger distinguishes between criminal and civil suits ${ }^{35}$ is absurd, that the defendant's tax liability should not depend upon the manner in which the Government chooses to institute its nontax claim against him. ${ }^{36}$ But, although it does not appear that the Supreme Court in Heininger intended that the case turn on the civil-criminal distinction, the importance which the Court attached to the difference is clearly indicated in its own statement of its holding: "the Board of Tax Appeals was not required to regard the administrative finding of guilt . . . as a rigid criterion of the deductibility of respondent's litigation expenses." ${ }^{37}$ The Court indicated that the crux of this distinction was the availability to the taxpayer convicted at a criminal trial of constitutional safeguards unavailable at administrative or other civil proceedings. Thus only after a criminal conviction would it have been appropriate in the Court's view to classify him as personally "guilty." 38

Thus viewed, the civil-criminal dichotomy suggests further similarities, generally ignored by the commentators, between fines and legal fees for purposes of deductibility. The argument has been advanced against the public policy exception in general that it is outside the competence of the Commissioner and Tax Court to determine, often years later, the

Arent, supra note 29, at 385-86; Krassner, supra note 29, at 448; Stapleton, The Supreme Court Redefines Public Policy, 30 TAXes 641 (1952); Note, 51 Colum. L. REv. 752, 758 (1951). Thus the question arises whether imperfections in nontax law should be allowed to justify positive action through the tax laws. Compare notes $41-42$ infra and accompanying text.

34 See, e.g., Jerry Rossman Corp. v. Commissioner, 175 F.2d 711, 713 (2d Cir. 1949) (L. Hand, J.) (dictum); Note, 51 ColvM. L. Rev. 752, 757 (1951). On the other hand, it is argued that disallowance may encourage prolonged litigation in the hopes of acquittal and discourage compromises. See, e.g., Comment, 72 Y ALE L.J. 108,135 (1962) ; 65 Colvm. L. Rev. 1108, 1114 (1965). "This may indeed be true with respect to penalties, see Universal Atlas Cement Co., 9 T.C. 971, 976 (1947) (dictum), aff'd per curiam, 171 F.2d 294 (2d Cir. 1948), cert. denied, 336 U.S. 962 (1949), but it seems clear that legal fees expended in the process of arriving at a compromise which does not involve an admission of guilt on the part of the taxpayer are deductible, see, e.g., Commissioner v. Schwartz, 232 F.2d 94 (5th Cir. 1956); Greene Motor Co., 5 T.C. 314 (1945), acq., 1945 CuM. Bull. 3; Longhorn Portland Cement Co., 3 T.C. 310 (1944), acq. in part, 1944 Cum. BuLL. 18, rev'd in part, 148 F.2d 276 (5th Cir.), cert. denied, 326 U.S. 728 (1945); Universal Atlas Cement Co., supra, at 975 (dictum).

It has been suggested that a distinction be made between good and bad faith defenses, see McDonald, supra note 13, at 181-82; Note, 51 ColUM. L. REv. 752, 757 (1951); however, such a determination, if not clearly beyond the competence of the Commissioner, would create serious administrative problems, see Comment, 72 Y YLE L.J. 108, 135 (1962). Compare notes 58-62 infra and accompanying text.

35 See note 21 supra and accompanying text.

36 See, e.g., Brookes, supra note 24, at 264; cf. Tellier v. Commissioner, 342 F.2d 690, 695 (2d Cir. 1965).

37 Commissioner v. Heininger, 320 U.S. 467, 475 (1943).

38 Id. at 474. 
legality of a taxpayer's activities or expenditures. ${ }^{39}$ However, where the taxpayer has already been convicted-as would always be the case with respect to claims for the deduction of attorneys' fees unsuccessfully expended as well as of fines, but not necessarily with respect to other types of expenses connected with unlawful activities ${ }^{40}$-the illegality has already been conclusively determined. A related argument against the general public policy exception involves the inappropriateness of judicially amending the Code to prosecute or harass suspected criminals who cannot be reached through state or federal penal laws. ${ }^{41}$ But with respect to attorneys' fees expended by a convicted man, just as with the fine he was required to pay, disallowance could have no such ulterior motive; the criminal has already been caught and punished. ${ }^{42}$

One frequently mentioned distinction between fines and legal fees, however, appears to stand up under scrutiny: Litigation expenses are not part of the criminal sanction. Their disallowance adds a punitive consequence, not prescribed by the penal law, which varies with the amount necessary for conducting a defense rather than with the severity of the crime, and which consequently may be unduly harsh relative to the statutory penalty. ${ }^{43}$ The Supreme Court has characterized the allowance of fines as "a device to avoid the consequence of violations of a law"; 44 the allowance of attorneys' fees does not so frustrate the punitive function of penal (1962).

39 See, e.g., Reid, supra note 11, at 578; Comment, 72 Y YIE L.J. 108, 124-25

40 See, e.g., Dixie Mach. Welding \& Metal Works, Inc. v. United States, 315 F.2d 439 (5th Cir.), cert. denied, 373 U.S. 950 (1963) (affirming determination by district court where suit brought for tax refund that expenditure violative of state statute); United States v. Winters, 261 F.2d 675 (10th Cir. 1958), cert. denied, 359 U.S. 943 (1959) (the same, with respect to prohibition statute unenforced by state).

${ }^{41}$ See, e.g., Lurie, supra note 12; Reid, supra note 11 . The use of tax evasion prosecutions to halt the careers of elusive racketeers appears to be a generally accepted procedure. Most cases, however, are based on the taxpayer's failure to report a large part of his income from illegal sources. See, e.g., United States v. Johnson, 319 U.S. 503 (1943); Schuermann v. United States, 174 F.2d 397 (8th Cir.), cert. denied, 338 U.S. 831 (1949). Such prosecutions would seem to be an appropriate function of the Internal Revenue Service. See Paul, supra note 16, at 737. On the other hand, it appears indefensible to contemplate, as some writers have done, see, e.g., Baker, Taxation: Potential Destroyer of Crime, 29 CEr--KeNT L. REv. 197, 217-21 (1951); cf. Comment, 39 CALIF. L. REv. 226 (1951), the use of the judicially created public policy exception to prosecute or harass the racketeer who actually reports and pays taxes on his "commercial net income." Such an approach would most likely ensnare many innocuous violators of complicated trade regulations and might, in fact, frustrate the intent of the framers of the Internal Revenue Code. See note 16 supra and accompanying text. See generally Paul, supra; 97 CoNG. REc. 12230-44 (1951).

42 Of course, to those advocating use of the tax laws for criminal law enforcement, who are primarily interested in disallowing the expenses of an unlawful business, this might provide one reason for allowing the deduction, at least in the case of the taxpayer conducting a legitimate business.

43 See, e.g., Krassner, supra note 29, at 448; Note, 51 CoL.ux. L. REv. 752, 757 (1951); Note, 54 HARv. L. REv. 852, 856 (1941); Note, 13 Stan. L. REv. 92, 102

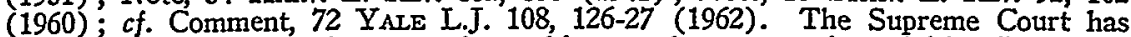
alluded to the inappropriateness of attaching to the taxpayer's activities "a serious punitive consequence" not intended by the legislation under which the nontax claim was brought. Commissioner v. Heininger, 320 U.S. 467, 474-75 (1943).

44 Commissioner v. Sullivan, 356 U.S. 27, 29 (1958). 
legislation. ${ }^{45}$ On the contrary, their disallowance may be thought to frustrate the policy embodied in the legislative determination of particular sanctions, ${ }^{46}$ as well as the more general policy that sanctions be known in advance and that they be the same for all similar violators.

In any case, the Supreme Court's frustration doctrine requires only that allowance of a deduction not frustrate public policy; it demands neither that the allowance positively aid law enforcement or further any other public policy nor that disallowance would be detrimental. This requirement would seem to be satisfied by the possibility of a neutrality in the administration of the tax laws vis-à-vis criminal legislation. ${ }^{47}$ The allowance of litigation expenses cannot fairly be said either to hinder the effectiveness or administration of the criminal law or to bestow any undue "benefit" on the taxpayer. ${ }^{48}$ This alone would seem sufficient to justify the Second Circuit's decision in the Tellier case.

Nevertheless, as the court of appeals indicated briefly in Tellier, ${ }^{49}$ some positive justification for its decision can be found through reference to the right to counsel guaranteed by the sixth and fourteenth amendments to the Constitution. ${ }^{50}$ First, the disallowance of attorneys' fees might discourage some taxpayers from defending against criminal charges. Although the courts at the time of Burroughs ${ }^{51}$ might have felt justified in replying that such would be a proper result, since primarily bad faith or unreasonable defenses would be deterred, ${ }^{52}$ the current view of an unqualified

45 Indeed, this point alone might be considered to compel deductibility if Sullivan, supra note 44, is read to imply that an otherwise "ordinary and necessary" expense must be allowed unless the allowance mitigates the penal sanction, the expenditure is illegal per se, or allowance is explicitly prohibited by the Code or by a Treasury Regulation which has gained congressional approval.

${ }_{46} \mathrm{Cf}$. Comment, 72 Y ALE L.J. 108, 127 (1962): "[T] he sanctional provisions of statutes . $\therefore$ are as integral a part of the federal or state policy toward these [illegal] activities as the proscription itself."

47 Neutral application of a graduated income tax is an elusive concept. One writer thinks neutrality impossible in the case of fines, taking the position that allowance decreases the prescribed sanction while disallowance increases the sanction by the amount of the additional tax liability. See Comment, 72 Y YLE L.J. 108, 117 (1962). Of course, either deductibility or nondeductibility will favor some taxpayers over others with respect to the actual burden of the fine. Nevertheless, it seems that, as in the case of attorneys' fees, the deductibility of fines would result in the only type of "neutrality" possible, i.e., the impact on a taxpayer in a given income bracket would be the same relative to his actual net income after taxes as it would to his net income if there were no income tax at all.

48 See, e.g., Keesling, sipra note 16, at 35 . There is no real "benefit" in the so-called "subsidy" of the violator's defense which some courts have emphasized. See, e.g., C. W. Thomas, 16 T.C. 1417,1418 (1951) ; Jerry Rossman Corp. v. Commissioner, 175 F.2d 711, 713 (2d Cir. 1949) (dictum).

49342 F.2d at 694 .

50 A concurring opinion by Chief Judge Lumbard joined by Judges Waterman and Kaufman-all of whom joined also in the opinion of the court by Judge Hayswas devoted to this point. 342 F.2d at 695-96.

51 Burroughs Bldg. Material Co. v. Commissioner, 47 F.2d 178 (2d Cir. 1931); see text accompanying notes $24-25$ supra.

52 See, e.g. Jerry Rossman Corp. v. Commissioner, 175 F.2d 711 (2d Cir. 1949) (dictum); cf. NTational Outdoor Advertising Bureau, Inc. v. Helvering, 89 F.2d 878, 881 (2d Cir. 1937) ("If it is never necessary to violate the law in managing a business, it cannot be necessary to resist a decree in equity forbidding violations, except in cases where an injunction is unjustified."). 
right to counsel casts doubt on any other policy which might conflict with it. ${ }^{53}$ Further, most litigation fees are attributable to a time when the defendant was presumptively innocent; the subsequent rebuttal of this presumption would not seem retroactively to change the nature of the expenditure made in pursuance of a constitutional right. The sixth and fourteenth amendments do not compel the allowance of deductions for expenses incurred in defending criminal prosecutions; ${ }^{54}$ it is unlikely that a new Code provision disallowing such deductions in the case of an unsuccessful defense would be deemed unconstitutional. However, once the attorneys' fees are conceded to be "ordinary and necessary" but for considerations of public policy, the national policy embodied in the right to counsel would seem to be furthered by allowing the deduction..$^{55}$

In addition, apparent injustice would result from disallowance where the convicted taxpayer has conducted a good faith defense. Frequently an accused does not know whether he is guilty until the judgment is handed down. ${ }^{56}$ Although it can be argued that such a person is a victim of the penal statutes rather than the tax law, a certain amount of vagueness and uncertainty in criminal legislation must be accepted as inevitable. Disallowance may also seem unjust as to the taxpayer who is found guilty of only one or some of several counts, or who is convicted of a crime of lesser degree than that charged in the indictment. Although some courts have attempted to solve this problem by crediting a portion of the taxpayer's litigation expenses to his partial success and disallowing the rest, ${ }^{57}$ such apportionment can be carried out only at the cost of administrative difficulty and an unavoidable element of arbitrariness. ${ }^{58}$

Indeed, administrative difficulties and seeming inequities provided the court in Tellier with a major justification for its decision. The court alluded to the "anomalous, arbitrary, artificial and conflicting results" to

$53 C f$., e.g., Gideon v. Wainwright, 372 U.S. 335 (1963). Although there may be a valid policy against unreasonable and bad faith defenses, as indicated, for example, by the practice of encouraging guilty pleas and settlements, the right to counsel does not depend on innocence or the reasonableness of the defense. See Tellier v. Commissioner, 342 F.2d 690, 696 (2d Cir. 1965) (concurring opinion).

54 Cf. Cammarano v. United States, 358 U.S. 498, 515 (1959) (Douglas, J., concurring); Walter F. Tellier, 22 CCH Tax Ct. Mem. 1062, 1071 (1963) (rev'd, Tellier v. Commissioner, supra note 53).

55 See, e.g., Arent, supra note 29, at 382; Brookes, supra note 24, at 267-68; Krassner, supra note 29, at 448; Winokur, supra note 31 ; Note, 13 STAN. L. REV. 92, 101-02 (1960); Comment, 72 Yale L.J. 108, 135-36 (1962).

56 See, e.g., Anthony Cornero Stralla, 9 T.C. 801 (1947). This problem arises particularly in the type of case most likely to involve a business claim for the allowance of litigation expenses-that involving trade regulation. See generally Paul, supra note 16, at 736; Note, 54 HARv. L. Rev. 852, 856 (1941); Comment, 72 YALE L.J. 108, 135 (1962).

57 See, e.g., National Outdoor Advertising Bureau, Inc. v. Helvering, 89 F.2d 878, 881 (2d Cir. 1937).

58 Cf., e.g., J. Reuel Campbell, CCH TAx CT. Rep. (TAx CT. Men. 1965-54) Dec. No. 27,284 (1965). Compare Standard Coat, Apron \& Linen Service, Inc., 40 T.C. 858 (1963), where the taxpayer's initial conviction was reversed, but the Tax Court refused to allow a deduction for any litigation expenses because of a subsequent nolo contenäere plea. 
which adherence to the Burroughs rule had led, ${ }^{59}$ then recounted the various types of tenuous borderline distinctions-between criminal and civil proceedings, ${ }^{60}$ guilt and innocence, ${ }^{61}$ and trial and pretrial expenses. ${ }^{62}$ The new rule announced by the Second Circuit will, of course, leave some administrative difficulties and anomalies remaining in the application of the public policy exception, particularly where attorneys' fees blend into the area of illegal or unethical expenditures. ${ }^{63}$ Thus the next step-after upholding and following the Tellier case-would seem to be a clarification of the issue of the deductibility of expenditures which have heretofore been considered in themselves against public policy. ${ }^{64}$

59342 F.2d at 694.

60 Compare text accompanying notes 36-39 supra.

61 For example, where a plea of nolo contendere was made for valid business reasons by a defendant subsequently determined to have been innocent, attorneys' fees have been disallowed. Bell v. Commissioner, 320 F.2d 953 (8th Cir. 1963). The Tax Court has held, on the other hand, that attorneys' fees expended in the settlement of criminal charges of tax evasion are deductible. Greene Motor Co., 5 T.C. 314 (1945), acq., 1945 Cum. Bull. 3.

62 This problem occurs most often with respect to convictions for tax evasion, where the taxpayer has attempted to persuade the government to seek only civil redress or has otherwise employed an attorney for investigatory services previous to indictment. Allocation has been made to allow a deduction for fees attributable to preindictment efforts. E.g., Hopkins v. Commissioner, 271 F. $2 d 166$ (6th Cir. 1959); Commissioner v. Schwartz, 232 F.2d 94 (5th Cir. 1956). But see Tracy v. United States, 151 Ct. Cl. 618, 284 F.2d 379 (1960).

63 Examples would be cases in which the taxpayer employs an attorney to help him conceal illegal business activities or in which the defense of a criminal charge is conducted unethically.

64 See note 15 supra. 